\title{
Efficiency and kinetics in treatment of wastewater from garages and residential oil spills using membrane bioreactor technology
}

\author{
M. C. Sichinga ${ }^{1} \cdot$ J. Frazee ${ }^{2} \cdot$ A. Z. Tong ${ }^{1}$
}

Received: 22 October 2014/Revised: 6 May 2015/Accepted: 6 July 2015 / Published online: 28 July 2015

(C) Islamic Azad University (IAU) 2015

\begin{abstract}
This research focused on the biodegradation of petrogenic hydrocarbons in wastewater using membrane bioreactor technology. Industrial oily wastewater with mixed fractions of hydrocarbons was collected and continuously treated for 50 days. Membrane bioreactor (MBR) effluent samples were analyzed daily for both aliphatic and aromatic hydrocarbons using gas chromatography-mass spectrometry. Many other water quality parameters were also measured including chemical oxygen demand, dissolved oxygen, turbidity, heavy metals and heterotrophic bacterial counts. These parameters were essential in evaluating the performance of the MBR treatment process. During the treatment period, 98.0, 96.0 and $99.8 \%$ removal of total aliphatic hydrocarbons in the lube oil fraction, total aliphatic hydrocarbons and total polycyclic aromatic hydrocarbons, respectively, were achieved. Overall, total organic removal, measured in terms of chemical oxygen demand, ranged from 88.3 to $92.6 \%$. Degradation kinetics was investigated for hydrocarbons and chemical oxygen demand. Half-lives of alkanes varied from several days to 40 days in the treatment process. Therefore, this study demonstrated that MBR is an effective treatment method for the removal of petroleum hydrocarbons in wastewater.
\end{abstract}

Keywords Half-life - Alkanes · Polycyclic aromatic hydrocarbons · Effluent $\cdot$ Petroleum · Biodegradation

A. Z. Tong

anthony.tong@acadiau.ca

1 Department of Chemistry, Acadia University, 6 University Avenue, Wolfville, NS B4P 2R6, Canada

2 E\&Q Consulting and Associates Limited, Wolfville, NS B4P 2R1, Canada

\section{Introduction}

Petroleum-contaminated wastewater is a complex mixture, and it may contain fuel, lubricating oil, grease and other additives. In conventional physicochemical methods, dissolved air floatation (DAF) is a commonly used method for removing suspended solids by releasing air bubbles to float suspended matter (Xu et al. 2014). In treating petroleumcontaminated wastewater with DAF, emulsified oil is removed by de-emulsification with hash chemicals, thermal energy or both. Air is then used to increase the buoyancy of smaller oil droplets and enhance separation. This method is very effective for liquid-solid separation; however, it is ineffective for dissolved hydrocarbons.

Membrane bioreactor technology (MBR) integrates biological degradation of waste products and membrane filtration (Lin et al. 2013; Ozgun et al. 2013). The use of submerged membranes for filtration allows for the elimination of or reduction in sedimentation tanks, which makes the MBR system compact and more efficient. It has the potential to overcome some of the problems being experienced in conventional wastewater treatment techniques. Some studies have been conducted to determine the applicability of MBR in petroleum wastewater. Abdollahzadeh et al. studied the treatment of high-salinity synthetic produced water using a submerged membrane bioreactor (Sharghi and Bonakdarpour 2013; Sharghi et al. 2013 , 2014). At an organic loading rate of $0.3-0.9 \mathrm{~kg} \mathrm{~m}^{-3}$ day $^{-1}$, oil and grease and chemical oxygen demand (COD) were removed 89.2-95.5 and $83 \%$ in their experiments, respectively. Khan et al. evaluated the performance of an aerobic bioreactor by treating wastewater from a biodiesel plants (Khan et al. 2015). It was determined that the average COD removal efficiency was about $95 \%$. Duan et al. verified four dominant bacterial 
consortium and studied the biodegradation of oily wastewater using a laboratory-size anaerobic/anoxic/aerobic MBR. They found that denaturing gradient gel electrophoresis was an effective method in identifying microorganisms in activated sludge (Duan et al. 2013). Wiszniowski et al. studied the removal of polycyclic aromatic hydrocarbons (PAHs) using MBR and monitored the bacterial community dynamics (Wiszniowski et al. 2011). It was observed that changing concentrations of PAHs did not affect effluent quality, as there was almost complete removal $(>99 \%)$ of PAHs throughout. Membrane sequencing batch reactor (MSBR) was also used in the treatment of synthetic and real produced wastewater by Pendashteh et al. (2010, 2012; Fakhru'l-Razi et al. 2010). The MSBR was investigated at various organic loading rates from 0.281 to $3.372 \mathrm{~kg} \mathrm{~m}^{-3} \mathrm{day}^{-1}$, and more than $90 \%$ removal rates were achieved for oil and grease and total organic carbon. Shariati et al. studied the impact of different hydraulic retention times (HRT) on the mixed liquor and removal efficiencies in treating synthetic petroleum refinery wastewater using MSBR (Shariati et al. 2011)

In this study, oily wastewater constituting a mix of garage and residential oil spills was treated using the MBR technology. This type of wastewater is ubiquitous and commonly accessible in everyday life. This real-world oily wastewater was treated continuously for 50 days. Various physical, chemical and microbiological water quality parameters were measured on a daily basis. In addition to total organic waste parameters such as COD and TPHs, performance of the MBR treatment system for individual hydrocarbons, especially different chain length alkanes, was evaluated in this study. Analytical methods for individual hydrocarbons were developed using solid-phase extraction (SPE) and gas chromatography-mass spectrometry (GC-MS). Further, biodegradation kinetics for these contaminants was investigated to understand the rates of biodegradation of petroleum compounds. The research was carried out at Acadia University (Wolfville, Nova Scotia, Canada) in 2013.

\section{Materials and methods}

\section{Reagents}

Standard mixes of alkanes, PAHs and semivolatile internal standards were supplied by Sigma-Aldrich Canada. Deuterated alkanes were acquired from CDN Isotopes Inc. (Quebec, Canada). The solvents used were of HPLC grade and supplied by Caledon (Ontario, Canada). Ultrahigh purity helium, acquired from Praxair (Nova Scotia, Canada), was used as the carrier gas for gas chromatography. Laboratory deionized water was used in preparation of blank and control samples. Agar, glucose, peptone and yeast extract were obtained from Sigma-Aldrich Canada.

\section{Wastewater}

In this study, actual industrial wastewater was used as feedstock. The wastewater was a mixture of local motor vehicle garage wastewater and residential oil spill wastewater. There was no oil slick floating on top of the wastewater; therefore, hydrocarbons were dissolved in the wastewater. This wastewater was left to settle for several days, divided into three layers, and transferred into separate bottles. This was a simple approach to mimic waste quality variations in industry. These three fractions were introduced into the bioreactor in sequence during the treatment experiments. The top layer had less suspended solids in comparison with the bottom layer, resulting in lower chemical oxygen demand. However, no noticeable differences were found for $\mathrm{pH}$, dissolved solids, dissolved hydrocarbons, etc. between layers, because dissolved matters do not settle. General characteristics of this oily wastewater (the bottom layer) are given in Table 1. It was noticed that the wastewater had a high $\mathrm{COD} / \mathrm{N}$ ratio; therefore, urea was added to boost the performance of the

Table 1 General characteristics of the wastewater

\begin{tabular}{ll}
\hline Parameter & Concentration \\
\hline COD & $1360 \mathrm{mg} / \mathrm{L}$ \\
Total organic carbon & $129 \mathrm{mg} / \mathrm{L}$ \\
Total petroleum hydrocarbons (TPH) & $18.8 \mathrm{mg} / \mathrm{L}$ \\
Total aliphatic hydrocarbons (TAH) & $8.71 \mathrm{mg} / \mathrm{L}$ \\
TAH-lube oil fraction (TAH-LO) & $5.96 \mathrm{mg} / \mathrm{L}$ \\
Total PAHs & $0.04 \mathrm{mg} / \mathrm{L}$ \\
Color & $660 \mathrm{PtCo}$ \\
Turbidity & $144 \mathrm{FTU}$ \\
Total suspended solids (TSS) & $93 \mathrm{mg} / \mathrm{L}$ \\
pH & 7.24 \\
Conductivity & $1070 \mu \mathrm{S} / \mathrm{cm}$ \\
Total dissolved solids (TDS) & $458 \mathrm{mg} / \mathrm{L}$ \\
Alkalinity & $76 \mathrm{mg} / \mathrm{L}$ \\
Total nitrogen & $7.17 \mathrm{mg} / \mathrm{L}$ \\
Ammonia & $0.04 \mathrm{mg} / \mathrm{L}$ \\
Nitrate & $<0.05 \mathrm{mg} / \mathrm{L}$ \\
Nitrite & $<0.05 \mathrm{mg} / \mathrm{L}$ \\
Chloride & $183 \mathrm{mg} / \mathrm{L}$ \\
Sulfate & $39 \mathrm{mg} / \mathrm{L}$ \\
Orthophosphate & $0.04 \mathrm{mg} / \mathrm{L}$ \\
Hardness & $251 \mathrm{mg} / \mathrm{L}$ \\
Dissolved sodium & $89.5 \mathrm{mg} / \mathrm{L}$ \\
Dissolved potassium & $4.6 \mathrm{mg} / \mathrm{L}$ \\
\hline & \\
\hline
\end{tabular}


MBR system. Before MBR treatment, the oily wastewater was filtered using 2.7- $\mu \mathrm{m}$ glass fiber filters (Fisher Scientific Canada) to remove large debris and suspended solids. This laboratory study focused on hydrocarbons, so prefiltration was used to eliminate interference of suspended solids. Since much coarser screens are used in industrial MBR systems, the impact of suspended solids should be carefully examined in pilot testing and industrial applications.

\section{Membrane bioreactor}

The MBR was a homemade system including a wastewater holding tank, a bioreactor and an effluent tank (Brown et al. 2013; Ghoshdastidar et al. 2012; Ghoshdastidar and Tong 2013). The bioreactor was a stainless steel cylindrical tank with a working volume of $21 \mathrm{~L}$. A SuperUF membrane module (Superstring MBR Technology Corp, China) was submerged in the bioreactor (Ghoshdastidar et al. 2012). The membrane was made of polyethylene with pore diameters around $20 \mathrm{~nm}$. The membrane module was in a tubular configuration and provided a total surface area of $0.40 \mathrm{~m}^{2}$. Transmembrane pressure was kept below $30 \mathrm{kPa}$, and no membrane cleaning was necessary during the experiment period. The bioreactor was aerated from a sparger in the base at a rate of $500 \mathrm{~L} / \mathrm{h}$ to ensure aerobic conditions. The effluent of the bioreactor was pumped at an average flow rate of $4.2 \mathrm{~mL} / \mathrm{min}$ using a peristaltic pump, which gave a HRT of 7 days. The bioreactor was initiated with $1 \mathrm{~L}$ of activated sludge obtained from a wastewater treatment plant in Dartmouth, Nova Scotia. Due to the short experimental period, sludge removal was not necessary. Since this experiment focused on bacterial population rather than the mixed liquor, activated sludge was simply assumed to remain in the bioreactor due to ultrafiltration; therefore, sludge retention was not measured. On a daily basis, effluent samples were collected for analysis including COD, color, turbidity, suspended solids, dissolved oxygen (DO), $\mathrm{pH}$ and total dissolved solids (TDS). Immediately after spectrometric and potentiometric analysis, another effluent sample was collected and placed in an airtight 1-L amber glass bottle with Teflon-lined cap. This sample was stored at $4{ }^{\circ} \mathrm{C}$ for further GC-MS analysis of alkanes and PAHs.

\section{General water quality analysis}

COD measurements were taken on a HACH DR2800 spectrophotometer. Color, TSS and turbidity were determined using a HACH DR2000 spectrophotometer. Conductivity, $\mathrm{DO}$ and $\mathrm{pH}$ measurements were taken using a HACH HQ40d multimeter. To ensure probe accuracy, they were calibrated on a weekly basis with appropriate calibration standards.

Oily wastewater and effluent samples were also collected and preserved for heavy metal analysis. These samples were sent to a commercial laboratory, AGAT Laboratories Limited (Dartmouth, NS), where heavy metals were quantified using inductively coupled plasma mass spectrometry (ICP-MS).

\section{Heterotrophic bacteria counts}

In this experiment, efforts were spent to find correlation between culturable bacterial population and concentrations of petroleum hydrocarbons. Therefore, heterotrophic bacteria counts were studied instead of mixed liquor suspended solids (MLSS) that are measured in engineering projects. The MBR bacteria culture was monitored using a heterotrophic plate count method as presented in the Standard Methods for the Examination of Water and Wastewater (Clesceri et al. 1989). Plate count agar was prepared with glucose, peptone and yeast extract. The solution was autoclaved at $118{ }^{\circ} \mathrm{C}$ for $20 \mathrm{~min}$ and then poured on sterile polystyrene petri dishes (Fisher Scientific). The agar plates were then stored at $4{ }^{\circ} \mathrm{C}$ to form a gel. Activated sludge samples were withdrawn from the MBR and then undergone serial dilutions using sterilized distilled water. A $0.5-\mathrm{mL}$ aliquot was inoculated on agar plates and incubated at $35{ }^{\circ} \mathrm{C}$ for $48 \mathrm{~h}$. After the incubation period, formed colonies on the plates were counted. To prevent contamination and addition of foreign bacterial populations, sterilization techniques recommended in the standard method were adhered to.

\section{Sample preparation of alkanes and PAHs}

Extraction of alkanes in MBR influent and effluent samples was conducted using (solid-phase extraction (SPE) with $3 \mathrm{~mL}$ Strata $\mathrm{CN}$ cartridges obtained from Phenomenex (California, USA). The SPE cartridge was packed with $500 \mathrm{mg}$ cyanopropyl $(\mathrm{CN})$ adsorbent with particle size distribution ranging from 20 to $80 \mu \mathrm{m}$ and pore size of $70 \AA$. The cartridge was conditioned with $20 \mathrm{~mL}$ of methanol, $50 \mathrm{~mL}$ hexane-dichloromethane $(50: 50) \mathrm{v} / \mathrm{v}$ mixture, $6 \mathrm{~mL}$ methanol and $6 \mathrm{~mL}$ distilled water. A water sample $(200 \mathrm{~mL})$ was aspirated through the SPE cartridge under vacuum at a rate of about $4 \mathrm{~mL} / \mathrm{min}$. Sample elution was done with three aliquots of $3 \mathrm{~mL}$ hexane-dichloromethane (50:50) v/v solvent. These extracts were pooled together and then concentrated by gently blowing down under nitrogen at $55^{\circ} \mathrm{C}$. The final sample volume was $1 \mathrm{~mL}$ which was transferred to GC-MS for instrumental analysis. 
Extraction of PAHs was conducted using $6 \mathrm{~mL}$ Strata PAH cartridges supplied by Phenomenex. The SPE cartridges were packed with $750 \mathrm{mg}$ sorbent mass. The cartridge was conditioned with $20 \mathrm{~mL}$ dichloromethane, then $20 \mathrm{~mL}$ methanol and finally equilibrating with $20 \mathrm{~mL}$ distilled water. Samples $(200 \mathrm{~mL})$ were then aspirated under vacuum. The sorbent was washed with $2 \mathrm{~mL}$ methanol-water mix (50:50, v/v) and then dried under vacuum. Sample elution was done with two aliquots of $2 \mathrm{~mL}$ dichloromethane and $2 \mathrm{~mL}$ toluene-dichloromethane $(50: 50, \mathrm{v} / \mathrm{v})$. These extracts were pooled together and concentrated to $1 \mathrm{~mL}$ by blowing down under nitrogen at $65{ }^{\circ} \mathrm{C}$.

\section{GC-MS analysis of alkanes and PAHs}

Quantitative analysis of alkanes and PAHs was carried out on an Agilent GC (7890A) coupled with a quadrupole MS (5975C). Chromatographic separation was conducted with a Phenomenex Zebron ZB-5HT capillary column (Torrance, USA) with a length of $30 \mathrm{~m}$, an internal diameter of $0.25 \mathrm{~mm}$ and $0.25 \mu \mathrm{m}$ film thickness. For alkanes, the GC oven was held at $80{ }^{\circ} \mathrm{C}$ for $2 \mathrm{~min}$, ramped at $10{ }^{\circ} \mathrm{C} / \mathrm{min}$ to $320^{\circ} \mathrm{C}$ and then held for $8 \mathrm{~min}$. For PAHs, the oven temperature started at $110{ }^{\circ} \mathrm{C}$ for $1 \mathrm{~min}$, ramped at $10{ }^{\circ} \mathrm{C} /$ min to $300{ }^{\circ} \mathrm{C}$ and then held for $5 \mathrm{~min}$. Ionization was achieved using an electron impact (EI) ion source operating in a selected ion monitoring (SIM) mode. Five-point internal calibration was established with quadratic regression and a forced zero intercept for each target analyte. In alkane analysis, $29 n$-alkanes $\left(\mathrm{C}_{10}-\mathrm{C}_{38}\right)$, pristane and phytane were included. For analysis of PAHs, 16 priority PAHs were selected as target analytes because they are among the most common petrogenic hydrocarbon pollutants (Monette 2014). Retention times and MS parameters of target compounds are listed in Tables 2 and 3.

\section{Quality assurance and quality control}

For quality control, dodecane-D26, tetracosane-D50 and triacontane-D62 were used as internal standards for quantitation of target alkanes, while decane-D22 and docosaneD46 were used as surrogate standards. Internal standards for PAH analysis were US-EPA 8270 semivolatile internal standards composed of naphthalene-D8, acenaphtheneD10, phenanthrene-D10, chrysene-D12 and perylene-D12. The surrogate for PAH analysis was $p$-terphenyl-D14. Blank samples were prepared to evaluate background contamination in solvents and sample preparation apparatus. Laboratory control samples (LCS) were used for method validation and optimization. It was noticed that minor contamination (mostly close or below MDL) was present. For contamination above MDL, the contribution of contamination was subtracted from the sample. Contamination levels varied from day to day. This can be attributed to the constant presence of petroleum-based products in the laboratory atmosphere and the environment in general. Precautions to reduce or eliminate contamination were taken into consideration. Actions such as isolating solvents, glassware and equipment cleaning and baking glassware were routinely done for this study. Reanalysis was performed in cases where results failed the QC criteria.

\section{Results and discussion}

\section{Temperature, $\mathrm{pH}$ and dissolved oxygen}

Figure 1 shows the DO concentration, temperature and $\mathrm{pH}$ of the effluent throughout the experimental period. It can be observed that the level of DO was well within the aerobic condition ( $\mathrm{DO} \geq 2 \mathrm{mg} / \mathrm{L}$ ). The average DO concentration was $6 \pm 1 \mathrm{mg} / \mathrm{L}$, with a maximum of $8 \mathrm{mg} / \mathrm{L}$ and a minimum of $3 \mathrm{mg} / \mathrm{L}$. The variation in DO appeared to be inversely correlated with the temperature change. However, in addition to the temperature, there are other parameters that can affect DO in an aerobic bioreactor, such as microbial oxygen consumption, $\mathrm{pH}$, oxygen transferring efficiency from its source and DO saturation concentration. These parameters often interact with each other, and the final DO observation in Fig. 1 was likely contributed by some or all of these parameters. There was a sharp decrease in DO at the beginning of the experiment. The introduction of oily wastewater increased bacterial activities, which consequently consumed more oxygen.

$\mathrm{pH}$ is one of the most important properties of wastewater as it influences the rate of biochemical reactions, which necessitates the need to control the $\mathrm{pH}$ over a narrow range. The average $\mathrm{pH}$ in this project was $6.6 \pm 0.6$, with a maximum and minimum $\mathrm{pH}$ of 7.4 and 5.2, respectively (Fig. 1b). The optimal $\mathrm{pH}$ range for biodegradation is usually within 6.5-7.5 (Sawyer et al. 2002), which was achieved most of the time during the experiment, although $\mathrm{pH}$ dropped below the range on some days. Low $\mathrm{pH}$ values were observed on Days 24, 31 and 39. The variations in $\mathrm{pH}$ had some moderate correlation with the temperature; as the temperature increased so did the $\mathrm{pH}$. This MBR study was conducted in winter months when several heating failures were experienced, which caused the temperature of the MBR to drop. Peters et al. proposed that the intermediate biodegradation products of petroleum hydrocarbons are their corresponding organic acids (Peters et al. 2005). Lower temperature might promote relatively more production of organic acids, which resulted in accumulation of acidic compounds and consequently lowering of $\mathrm{pH}$ (Reyes-Avila et al. 2013). On the other side, the rate of 
Table 2 List of alkanes, analytical parameters and treatment effects

\begin{tabular}{|c|c|c|c|c|c|c|c|c|c|c|}
\hline $\mathrm{C} \#$ & Compound name & PI & SI & $\mathrm{RT}(\min )$ & $\operatorname{LCSR}(\%)$ & MDL $(\mu \mathrm{g} / \mathrm{L})$ & $\mathrm{C}_{\text {oww }}(\mu \mathrm{g} / \mathrm{L})$ & $\mathrm{C}_{\mathrm{eff}, 50}(\mu \mathrm{g} / \mathrm{L})$ & Reduction (\%) & Half-life (day) \\
\hline 10 & $n$-Decane & 71 & 85 & 3.94 & 80 & 0.019 & 72.77 & 0.038 & 99.9 & - \\
\hline 11 & $n$-Undecane & 71 & 85 & 5.49 & 86 & 0.014 & 78.93 & 0.076 & 99.9 & 10 \\
\hline 12 & $n$-Dodecane & 71 & 85 & 7.01 & 90 & 0.004 & 90.31 & 0.216 & 99.8 & - \\
\hline 13 & $n$-Tridecane & 71 & 85 & 8.45 & 93 & 0.004 & 91.77 & 0.238 & 99.7 & - \\
\hline 14 & $n$-Tetradecane & 71 & 85 & 9.81 & 100 & 0.005 & 83.15 & 0.238 & 99.7 & - \\
\hline 15 & $n$-Pentadecane & 71 & 85 & 11.08 & 104 & 0.005 & 78.35 & 0.152 & 99.8 & 14 \\
\hline 16 & $n$-Hexadecane & 85 & 71 & 12.28 & 105 & 0.006 & 59.91 & 0.335 & 99.4 & 19 \\
\hline 17 & $n$-Heptadecane & 71 & 85 & 13.42 & 108 & 0.006 & 70.80 & 0.807 & 98.9 & 11 \\
\hline 19 & Pristane & 71 & 85 & 13.49 & 102 & 0.003 & 47.64 & 0.344 & 99.3 & 28 \\
\hline 18 & n-Octadecane & 71 & 85 & 14.49 & 108 & 0.005 & 63.30 & 0.270 & 99.6 & 22 \\
\hline 20 & Phytane & 71 & 85 & 14.60 & 101 & 0.004 & 32.92 & $<0.004$ & $>99.9$ & - \\
\hline 19 & $n$-Nondecane & 71 & 85 & 15.52 & 113 & 0.006 & 27.64 & 0.550 & 98.0 & 23 \\
\hline 20 & $n$-Eicosane & 71 & 85 & 16.50 & 87 & 0.004 & 21.72 & 0.237 & 98.9 & - \\
\hline 21 & $n$-Heneicosane & 71 & 85 & 17.43 & 83 & 0.003 & 19.42 & 0.100 & 99.5 & 3 \\
\hline 22 & $n$-Docosane & 71 & 85 & 18.33 & 95 & 0.004 & 18.93 & 0.609 & 96.8 & - \\
\hline 23 & $n$-Tricosane & 71 & 85 & 19.19 & 87 & 0.001 & 24.38 & 0.056 & 99.8 & 10 \\
\hline 24 & $n$-Tetracosane & 71 & 85 & 20.01 & 97 & 0.004 & 31.40 & 0.316 & 99.0 & 9 \\
\hline 25 & $n$-Pentacosane & 71 & 85 & 20.80 & 98 & 0.003 & 23.22 & 0.110 & 99.5 & 3 \\
\hline 26 & $n$-Hexacosane & 71 & 85 & 21.57 & 89 & 0.003 & 12.25 & 0.202 & 98.4 & 10 \\
\hline 27 & $n$-Heptacosane & 71 & 85 & 22.30 & 94 & 0.003 & 14.33 & 0.280 & 98.0 & 19 \\
\hline 28 & n-Octacosane & 71 & 85 & 23.01 & 90 & 0.006 & 15.70 & 0.166 & 98.9 & - \\
\hline 29 & $n$-Nonacosane & 71 & 85 & 23.70 & 91 & 0.007 & 6.42 & 0.105 & 98.4 & 20 \\
\hline 30 & $n$-Triacontane & 71 & 85 & 24.37 & 85 & 0.005 & 5.64 & 0.099 & 98.3 & 40 \\
\hline 31 & $n$-Hentriacontane & 71 & 85 & 25.01 & 86 & 0.007 & 6.87 & 0.104 & 98.5 & - \\
\hline 32 & $n$-Dotriacontane & 71 & 85 & 25.63 & 88 & 0.008 & 10.00 & 0.179 & 98.2 & - \\
\hline 33 & $n$-Tritriacontane & 71 & 85 & 26.24 & 84 & 0.014 & 2.96 & 0.048 & 98.4 & - \\
\hline 34 & $n$-Tetratriacontane & 71 & 85 & 26.90 & 82 & 0.010 & 7.73 & 0.113 & 98.5 & 17 \\
\hline 35 & $n$-Pentatriacontane & 71 & 85 & 27.63 & 81 & 0.014 & $<0.014$ & $<0.014$ & - & - \\
\hline 36 & $n$-Hexatriacontane & 71 & 85 & 28.47 & 84 & 0.020 & $<0.020$ & $<0.020$ & - & - \\
\hline 37 & $n$-Heptatriacontane & 71 & 85 & 29.43 & 79 & 0.015 & $<0.015$ & $<0.015$ & - & - \\
\hline 38 & $n$-Octatriacontane & 71 & 85 & 30.56 & 76 & 0.022 & $<0.022$ & $<0.022$ & - & - \\
\hline
\end{tabular}

$P I$ primary ion $(\mathrm{m} / \mathrm{z}), S I$ secondary ion $(\mathrm{m} / \mathrm{z}), R T$ retention time, $M D L$ method detection limit, $L C S R$ laboratory control sample recovery, $C_{\text {oww }}$ concentration in oily wastewater, $C_{e f f, 50}$ concentration in effluent on Day $50,-$ not applicable or calculated

nitrification might increase, which could also cause $\mathrm{pH}$ to increase. To raise $\mathrm{pH}$, potassium hydroxide was added to the bioreactor in those low $\mathrm{pH}$ days. Alternatively, a phosphate buffer system may be used to keep the $\mathrm{pH}$ consistent. However, such a buffering system may not be easily applied in an industrial-size bioreactor.

\section{Color, turbidity and suspended solids}

Color, turbidity and total suspended solids (TSS) are important esthetic parameters in water quality analysis and treatment efficiency assessment. Color and turbidity are related to both suspended matter and dissolved substances (organics and inorganics), while TSS depends on suspended matter only. Health Canada regulates these parameters in drinking water for esthetic reasons, although an objective of 15 PtCo was set for color (FederalProvincial-Territorial Committee on Drinking Water 2014). Regulations on these parameters in industrial wastewater depend on the substances contributing to color and their effects on human health and the environment (Monette 2014).

The oily wastewater in this experiment had $660 \mathrm{PtCo}$ of color before treatment. Effluent color showed an average of $80 \pm 20$ PtCo with a final color of 89 PtCo on Day 50. This change in color translates to a reduction of $88 \%$, from wastewater to effluent, achieved by the MBR treatment method. The influent's turbidity was 144 FTU, while the 
Table 3 List of PAHs, analytical parameters and treatment effects

\begin{tabular}{|c|c|c|c|c|c|c|c|c|}
\hline Compound name & PI & SI & RT (min) & LCSR (\%) & MDL $(\mu \mathrm{g} / \mathrm{L})$ & $\mathrm{C}_{\text {oww }}(\mu \mathrm{g} / \mathrm{L})$ & $\mathrm{C}_{\mathrm{eff}, 50}(\mu \mathrm{g} / \mathrm{L})$ & Reduction (\%) \\
\hline Naphthalene & 128 & 129 & 4.10 & 91 & 0.003 & 18.90 & 0.009 & $>99.9$ \\
\hline Acenaphthylene & 152 & 151 & 7.13 & 99 & 0.009 & 0.443 & 0.030 & 93.2 \\
\hline Acenaphthene & 153 & 154 & 7.54 & 98 & 0.004 & 1.986 & 0.012 & 99.4 \\
\hline Fluorene & 166 & 165 & 8.67 & 101 & 0.005 & 5.678 & $<0.005$ & $>99.9$ \\
\hline Phenanthrene & 178 & 176 & 10.86 & 100 & 0.003 & 10.86 & 0.014 & $>99.9$ \\
\hline Anthracene & 178 & 176 & 10.97 & 94 & 0.014 & 0.549 & $<0.014$ & 97.5 \\
\hline Fluoranthene & 202 & 200 & 13.68 & 100 & 0.007 & 0.715 & 0.019 & 97.4 \\
\hline Pyrene & 202 & 200 & 14.19 & 102 & 0.006 & 2.729 & $<0.006$ & 99.8 \\
\hline Benz $[a]$ anthracene & 228 & 226 & 17.06 & 106 & 0.011 & 0.280 & $<0.011$ & 96.0 \\
\hline Chrysene & 228 & 226 & 17.15 & 92 & 0.009 & 0.339 & $<0.009$ & 97.2 \\
\hline Benzo $[b]$ fluoranthene & 252 & 253 & 19.48 & 93 & 0.006 & 0.478 & $<0.006$ & 98.8 \\
\hline Benzo $[k]$ fluoranthene & 252 & 253 & 19.53 & 86 & 0.003 & 0.129 & $<0.003$ & 97.7 \\
\hline Benzo $[a]$ pyrene & 252 & 253 & 20.12 & 95 & 0.007 & 0.281 & $<0.007$ & 97.5 \\
\hline Indeno $[1,2,3-c, d]$ pyrene & 276 & 277 & 22.80 & 103 & 0.009 & 0.103 & $<0.009$ & 91.5 \\
\hline Dibenzo $[a, h]$ anthracene & 278 & 279 & 22.88 & 104 & 0.004 & 0.033 & $<0.004$ & 88.4 \\
\hline $\operatorname{Benzo}[g, h, i]$ perylene & 276 & 277 & 23.51 & 103 & 0.010 & 0.485 & $<0.010$ & 98.0 \\
\hline
\end{tabular}

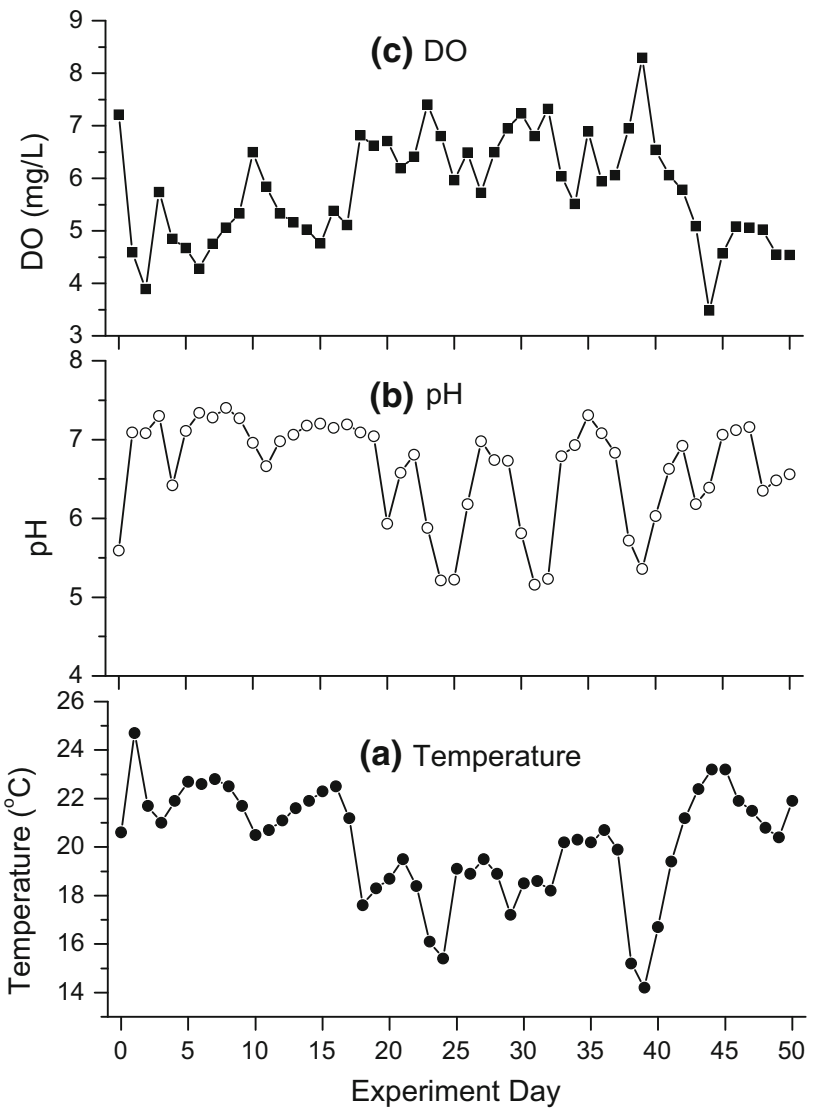

Fig. 1 Temperature, $\mathrm{pH}$ and dissolved oxygen in MBR effluent

effluent had an average of $16 \pm 4$ FTU with a final turbidity of 17 . In comparison with the oily wastewater, a turbidity reduction of $90 \%$ was achieved by the MBR treatment method. These considerable reductions in color and turbidity can be attributed to the efficiency of microorganisms in consuming waste as a source of nutrients and the ultrafiltration of membrane. Membrane filtration should also be credited in this reduction, as large debris and molecules were retained in the bioreactor and accumulated in the bioreactor.

Prior to MBR treatment, the oily wastewater had a TSS concentration of $93.0 \mathrm{mg} / \mathrm{L}$. During the treatment period, TSS remained consistently low. The average TSS of the effluent was $1.1 \pm 0.7 \mathrm{mg} / \mathrm{L}$ with a final TSS of $1 \mathrm{mg} / \mathrm{L}$ on Day 50. A removal efficiency of $99 \%$ was achieved, and this was attributed to the performance of the membrane module. In conventional wastewater treatment plant, TSS is usually removed by deposition of settleable solids in clarifiers, which is influenced by hydrodynamic conditions (Sawyer et al. 2002). In an aerobic MBR, TSS is usually retained by membrane ultrafiltration, which results in long SRT and TSS accumulation in the mixed liquor. Regular sludge removal can be employed in MBR maintenance to remove excessive TSS and debris from the bioreactor to prevent solid accumulation.

\section{Microbiological analysis}

In MBR, microbial degradation is essential for the biological treatment method. Therefore, it is important to monitor the bacterial population in the activated sludge. Heterotrophic plate counts (HPC) were measured in triplicates, and averaged results are depicted in Fig. 2. Due to the magnitude of population change, HPC is plotted in a logarithmic scale. There was a steady increase in bacterial 


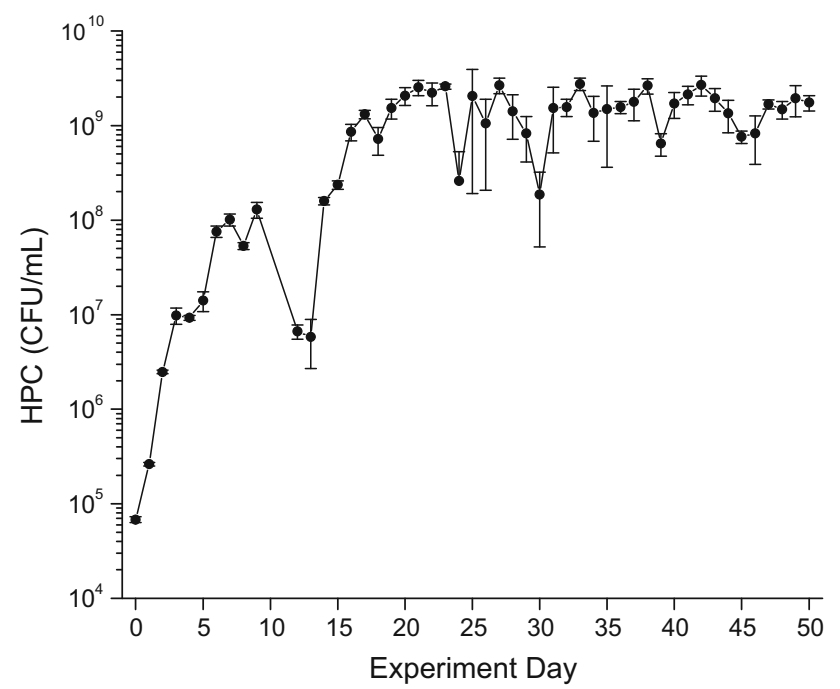

Fig. 2 Heterotrophic bacterial counts in MBR effluent

population from $6.79 \times 10^{4}$ to $2.54 \times 10^{9} \mathrm{CFU} / \mathrm{mL}$ in 21 days, which was five orders of magnitude. After Day 21, HPC became stabilized and reached a steady state within a short period of acclimatization. Martin-Pascual et al. discovered that the rate of organic matter removal was correlated with the heterotrophic biomass in membrane bioreactor treatment that was significantly affected by the temperature and hydraulic retention time (MartínPascual et al. 2014).

\section{Chemical oxygen demand}

In this experiment, the chemical oxygen demand (COD) of oily wastewater was $861 \mathrm{mg} / \mathrm{L}$ in the first 30 days (top layer), increased to $1200 \mathrm{mg} / \mathrm{L}$ in the next 15 days (middle layer) and finished with $1360 \mathrm{mg} / \mathrm{L}$ in the last 5 days (bottom layer). Variation of organic waste load in wastewater is common in industrial-scale applications, and this change in COD was a way to test the stability of the MBR treatment method.

The COD of effluent increased sharply to a maximum of $669 \mathrm{mg} / \mathrm{L}$ in a day once the oily wastewater was pumped in (Fig. 3a). Because the bacterial population increased quickly in acclimation (Fig. 2), the effluent COD decreased gradually until it reached $90 \mathrm{mg} / \mathrm{L}$ on Day 21 . Slight fluctuation was observed between Day 22 and Day 30, which was caused by the decrease in temperature and $\mathrm{pH}$ during the period. It is interesting to notice that the effluent COD kept stable after Day 31, despite further bumps of the temperature and $\mathrm{pH}$. Further, the influent COD increases on Day 30 and Day 45 did not show any measurable impact on the effluent COD. The decreasing trend of the effluent COD appeared to follow an exponential decay. Therefore, a first-order reaction was assumed to model the kinetics of

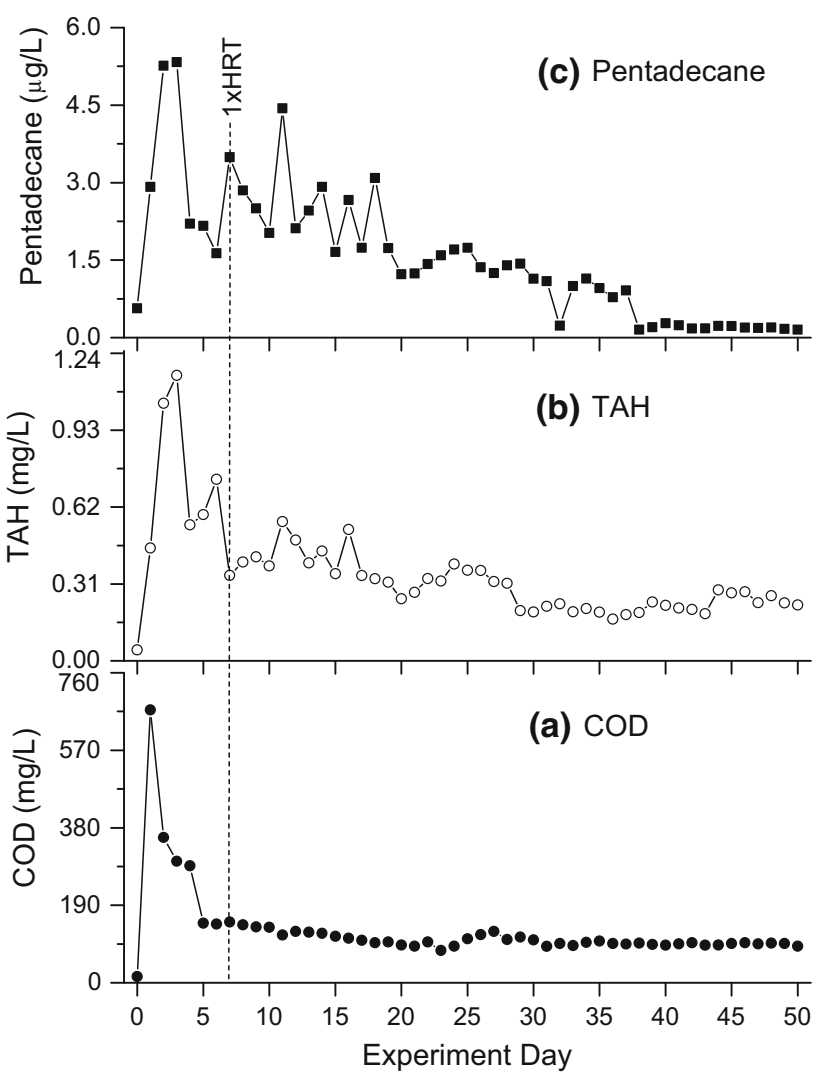

Fig. 3 Chemical oxygen demand, total aliphatic hydrocarbons and pentadecane in MBR effluent

the decomposition process. The initial period of acclimation was not included in the exponential regression. A lifetime of $2.0 \pm 0.1$ days was obtained after exponential fitting of the experimental results. Thus, the half-life, a commonly used parameter in kinetic evaluation, was determined to be 1.4 days. In first-order kinetics, both lifetime and half-life are independent of the initial concentration of the system. An asymptote was calculated to be $103 \pm 3 \mathrm{mg} / \mathrm{L}$, which corresponded to $92.6 \%$ removal of total organics when the MBR system reached a steady state. A rate of biodegradation at the steady state was calculated to be $15.3 \mathrm{mg} / \mathrm{L} / \mathrm{h}$. The removal rate may be further improved by injecting pure oxygen instead of air into the bioreactor, which can significantly boost the enzymatic activity in biodegradation (Dorival-García et al. 2014).

\section{Alkanes}

Solid-phase extractions were performed to prepare samples for GC-MS analysis. Table 2 shows the averaged recoveries of control samples during the experiment. Recoveries of target compounds were within the range of $76-108 \%$. It was observed that light compounds had relatively low 
extraction efficiency. This could be attributed to their high volatility, resulting in loss due to evaporation. The same trend was observed for heavy alkanes, which might be attributed to their low solubility in water or low affinity to the elution solvent. Method detection limits (MDLs) after sample preparation were determined in the low $\mathrm{ng} / \mathrm{L}$ range (Table 2).

Individual alkanes were analyzed to evaluate the performance of the MBR for aliphatic hydrocarbons with different molecular weights. Experimental results were important to understand the biodegradation kinetics of these compounds. The concentrations of alkanes in the oily wastewater before MBR treatment are listed in Table 2. A total ion chromatogram (TIC) of the oily wastewater is shown in Fig. 4a. This hydrocarbon distribution falls in the range of diesel fuel, which matches the sources of the wastewater (garage waste and heating oil spills). Within this range, $n$-alkanes showed much higher concentrations than their branched isomers; therefore, $n$-alkane peaks were well resolved. Further, there was an unresolved hump between the retention times of $n$-heneicosane (17.43 min) and $n$-hexatriacontane (28.47 $\mathrm{min})$. This hump was caused by significant presence of branched isomers. This fraction fit the ranges of lubricating oil, which was again expected in garage wastewater. This hump was used to determine the total aliphatic hydrocarbons in the lubricating oil fraction (TAH-LO). Similarly, total aliphatic hydrocarbons (TAH) were also calculated to include all aliphatics across the entire chromatogram. The initial TAH and TAH-LO in the oily wastewater prior to bioreactor treatment were 8.71 and $5.96 \mathrm{mg} / \mathrm{L}$, respectively. TAH-LO constituted about $68.4 \%$ of the analyzed petroleum content. TAH, TAH-LO and individual hydrocarbons were dissolved compounds, so

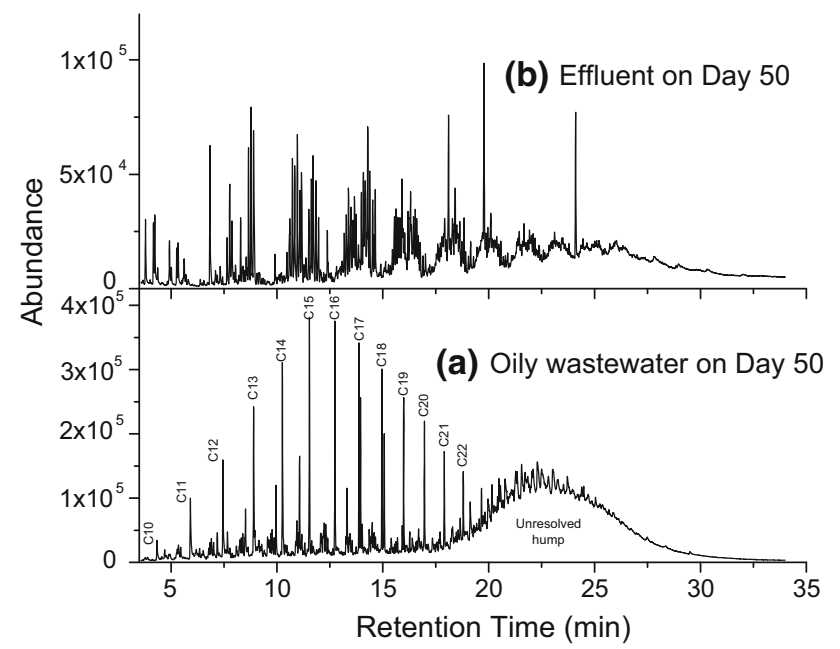

Fig. 4 Total ion chromatograms of alkanes in the wastewater and the effluent on Day 50 their concentrations were the same in different layers of the wastewater.

A TIC of the effluent on Day 50 is plotted in Fig. 4b. In comparison with the TIC of the oily wastewater, there were significant reductions in the lubricating oil hump, baseline and target $n$-alkanes. However, the effluent TIC was noisier than that of the oily wastewater. The background noise peaks likely were metabolites produced in biodegradation processes. Alkane concentrations in the wastewater and the effluent on Day 50 are given in Table 2. More than $98 \%$ of reductions were achieved for all target alkanes. $n$-Alkanes from C35 to C38 were not evaluated because their concentrations were below MDLs. Phytane was not detected in the effluent, while its adjacent alkanes were observed well above MDLs. This indicated that phytane has a higher rate of degradation, but pristine was not observed for a similar effect. Equal numbers of $n$-alkanes from C10 to C33 were selected to calculate the ratio of evens to odds $\left(R_{\mathrm{e} / \mathrm{o}}\right)$. The $R_{\text {e/o }}$ was 1.09 in the oily wastewater, which was slightly less than the $R_{\mathrm{e} / \mathrm{o}}$ of 1.11 in the effluent. This difference was within the experimental error, which indicated the biodegradation of $n$-alkanes during treatment was not selective on the symmetry of carbon chain length. Furthermore, the effluent TAH and TAH-LO concentrations on Day 50 were 0.226 and $0.079 \mathrm{mg} / \mathrm{L}$, respectively. In comparison with their concentration in the wastewater, TAH and TAH-LO were removed by 97.4 and $98.7 \%$, respectively. The ratio of TAH-LO in TAH dropped from 68.4 to $35.0 \%$ after treatment. Therefore, MBR treatment appeared to be more efficient in removal of higher molecular mass alkanes than lighter ones. Another possibility could be that heavier alkanes were decomposed into lighter alkanes, resulting in an increased ratio of low molecular mass compounds as a net effect. Concentrations of individual alkanes across the treatment period showed observable fluctuations, especially in early treatment days. Once the MBR system reached a steady state, their concentrations were stabilized. The results of TAHs and pentadecane in the effluent during the treatment period are shown in Fig. 3. Alkane concentrations followed moderately exponential decays with respect to time. First-order kinetics was used for data modeling, and half-lives of individual alkanes were calculated if possible (Table 2). Half-lives of organic contaminants in a biological treatment system show the time needed for the system to acclimate to new contaminants and are related to the rates of degradation of these contaminants in a dynamic system. Although MBR is operated continuously under steady state conditions, it is still important to understand half-lives. The normal heneicosane and pentacosane had the shortest halflife of 3 days, while the normal triacontane showed the longest half-life of 40 days. There was a linear TAH increase during the first 3 days of the experiment, while the 
COD reached a maximum in a day. This comparison of the number of days before peak concentrations might not be accurate, because the MBR system varied significantly within the first HRT. The TAH was then decreased gradually with some variations and reached a steady state on Day 29, which was similar to the trend of COD. Both TAH and TAH-LO followed exponential decays. The half-lives of TAH and TAH-LO were determined to be 4.9 and 9.2 days, which were much longer than the COD's half-life of 1.4 days. The long half-life of TAH-LO indicated that heavy aliphatic hydrocarbons (lubricating oil fraction) were slower to biodegrade in comparison with lighter aliphatics under an aerobic condition. The same trend was also observed by Peters et al., because normal alkanes of greater chain length were more difficult to transport across bacterial cell membranes (Peters et al. 2005).

\section{Polycyclic aromatic hydrocarbons}

Strata PAH cartridges were used in preparation of water samples for PAH analysis. The percentage extraction efficiencies in LCS are given in Table 3. Recoveries of laboratory control samples ranged from 86 to $106 \%$. Blank contamination was observed for naphthalene. A blank correction was done for samples that needed to be adjusted. MDLs were determined at a low $\mathrm{ng} / \mathrm{L}$ level as listed in Table 3.

Figure 5a shows a chromatogram of PAHs in the oily wastewater. It can be observed that the most abundant compounds were naphthalene, fluorene and phenanthrene. The 16 target PAHs in the oily wastewater were present on the level of low $\mu \mathrm{g} / \mathrm{L}$ (Table 3 ). Concentrations of naphthalene, fluorene and phenanthrene were 18.9, 5.68 and

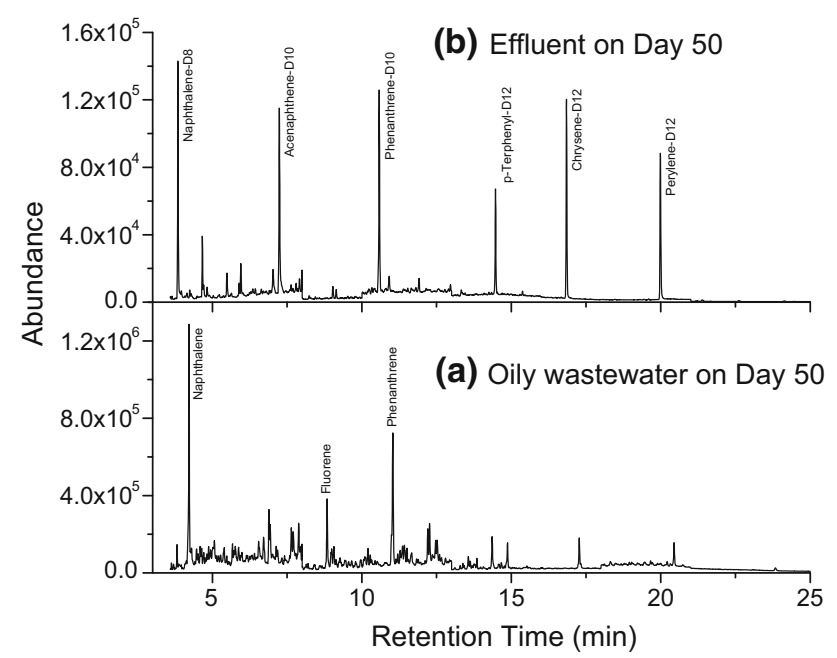

Fig. 5 Total ion chromatograms of PAHs in the wastewater and the effluent on Day 50
$18.9 \mu \mathrm{g} / \mathrm{L}$, respectively. The total concentration of the 16 PAH was $44.0 \mu \mathrm{g} / \mathrm{L}$. Its contribution to the total hydrocarbon load was rather small in comparison with that of alkanes $(8.71 \mathrm{mg} / \mathrm{L})$. However, it was important to evaluate MBR treatment of aromatic organic compounds.

The chromatogram of the effluent on Day 50 is shown in Fig. 5b. The ion abundance of the effluent sample was much less than that of the oily wastewater. Only trace amounts of PAHs could be observed while major chromatographic peaks in Fig. 5b are internal and surrogate standards. The total PAH concentration in the effluent on Day 50 was $0.097 \mu \mathrm{g} / \mathrm{L}$. This represents an overall reduction of $99.8 \%$ after treatment. Such high removal efficiency could be attributed to quick microbial acclimatization to aromatic chemicals. The structure of molecules might also play an important role. PAHs are generally round molecules and rich of $\pi$ electrons, which is different to linear alkane molecules with no $\pi$ electrons. Therefore, PAH molecules may have higher binding to enzymes in bacteria (Peters et al. 2005).

Individual PAHs in the effluent did not demonstrate a particular biodegradation trend, except for naphthalene which weakly followed an exponential decay. The major variations of PAH concentrations in the effluent were close to or even below MDLs, because PAHs were effectively removed and their initial concentrations in the oily wastewater were low. The concentration of naphthalene in the effluent started at $20.5 \mathrm{ng} / \mathrm{L}$, rose to a maximum of $51 \mathrm{ng} / \mathrm{L}$ and then quickly dropped to an equilibrium concentration around $10 \mathrm{ng} / \mathrm{L}$. Using a first-order kinetics for modeling, the half-life of naphthalene was calculated to be 2.9 days.

\section{Other organic constituents}

The COD of the oily wastewater $(1.36 \mathrm{~g} / \mathrm{L})$ was much higher than the observed concentrations of the total petroleum hydrocarbons $(18.75 \mathrm{mg} / \mathrm{L})$. This indicates that there were significant other organic compounds contributing to the organic load in the wastewater. Attempts to identify other organic compounds were made using gas chromatography with flame ionization detector (GC-FID), GC-MS and FTIR. Ethylenediamine was identified as a major organic compound in the wastewater. Ethylenediamine has been used as a heavy duty detergent for cleaning and metalworking fluid in industry. Its concentration in the wastewater was determined to be $386 \mathrm{mg} / \mathrm{L}$. A concentration of $36 \mathrm{mg} / \mathrm{L}$ in the effluent was observed on the second day of the experiment, while its concentrations were below the detection limit $(30 \mathrm{mg} / \mathrm{L})$ in other days. This implies that at least $91 \%$ of ethylenediamine was removed in the treatment process. 
Table 4 Metal concentrations of wastewater and MBR effluent

\begin{tabular}{|c|c|c|c|c|c|}
\hline Parameter & $\operatorname{MDL}(\mu \mathrm{g} / \mathrm{L})$ & Wastewater $(\mu \mathrm{g} / \mathrm{L})$ & Effluent $(\mu \mathrm{g} / \mathrm{L})$ & Percent reduction & $\operatorname{MAC}(\mu \mathrm{g} / \mathrm{L})$ \\
\hline Aluminum & 5 & 9 & $<5$ & $>44 \%$ & - \\
\hline Antimony & 2 & 75 & 34 & $55 \%$ & 6 \\
\hline Arsenic & 2 & 2 & $<2$ & $\mathrm{~N} / \mathrm{C}$ & 25 \\
\hline Barium & 5 & 50 & $<5$ & $>90 \%$ & 1000 \\
\hline Beryllium & 2 & $<2$ & $<2$ & $\mathrm{~N} / \mathrm{C}$ & 4 \\
\hline Bismuth & 2 & $<2$ & $<2$ & $\mathrm{~N} / \mathrm{C}$ & - \\
\hline Boron & 5 & 3730 & 1960 & $47 \%$ & 5000 \\
\hline Cadmium & 0.017 & 2.32 & 1.79 & $23 \%$ & 5 \\
\hline Chromium & 1 & 4 & $<1$ & $>75 \%$ & 50 \\
\hline Cobalt & 1 & 2 & $<1$ & $>50 \%$ & - \\
\hline Copper & 2 & 1280 & 217 & $83 \%$ & 1300 \\
\hline Iron & 50 & 386 & $<50$ & $>87 \%$ & $\leq 300$ \\
\hline Lead & 0.5 & 6.3 & 3.3 & $48 \%$ & 10 \\
\hline Manganese & 2 & 85 & 71 & $16 \%$ & $\leq 50$ \\
\hline Molybdenum & 2 & 1400 & 758 & $46 \%$ & - \\
\hline Nickel & 2 & 7 & 13 & Increase & - \\
\hline Selenium & 1 & 3 & 1 & $67 \%$ & 10 \\
\hline Silver & 0.1 & $<0.1$ & $<0.1$ & $\mathrm{~N} / \mathrm{C}$ & - \\
\hline Strontium & 5 & 197 & 131 & $34 \%$ & - \\
\hline Thallium & 0.1 & $<0.1$ & $<0.1$ & $\mathrm{~N} / \mathrm{C}$ & 2 \\
\hline Tin & 2 & $<2$ & $<2$ & $\mathrm{~N} / \mathrm{C}$ & - \\
\hline Titanium & 2 & $<2$ & $<2$ & $\mathrm{~N} / \mathrm{C}$ & - \\
\hline Uranium & 0.1 & 0.2 & $<0.1$ & $\mathrm{~N} / \mathrm{C}$ & 30 \\
\hline Vanadium & 2 & $<2$ & $<2$ & $\mathrm{~N} / \mathrm{C}$ & - \\
\hline Zinc & 5 & 168 & 320 & Increase & $\leq 5000$ \\
\hline
\end{tabular}

- not available

\section{Heavy metals}

Heavy mental compositions were analyzed for the oily wastewater and final MBR effluent as given in Table 4. Canadian Council of Ministers of the Environment has guidelines on the maximum acceptable concentrations (MACs) of metals in wastewater, which are also included in the table for reference (Canadian Council of Ministers of the Environment 2003).

The oily wastewater did not contain high levels of metals as expected for the source of wastewater. There were three metals with concentrations above $1 \mathrm{mg} / \mathrm{L}$ : boron $(3.73 \mathrm{mg} / \mathrm{L})$, copper $(1.28 \mathrm{mg} / \mathrm{L})$ and molybdenum $(1.40 \mathrm{mg} / \mathrm{L})$. Various removal percentages after treatment were observed for different metals, ranging from $16 \%$ for manganese up to $>90 \%$ for barium. Antimony $(34 \mu \mathrm{g} / \mathrm{L})$ in the effluent was the only metal above the MAC $(6 \mu \mathrm{g} / \mathrm{L})$, although a $55 \%$ reduction was achieved during the treatment. Increment from wastewater to effluent was observed for nickel and zinc. This might be attributed to leaching from stainless steel used in the bioreactor construction. Further, nickel and zinc have relatively high ion mobility, resulting low treatment efficiency. Some metals had influent and effluent concentrations close or below the MDLs; therefore, accurate evaluation of MBR treatment could not be established. In a biological treatment process, heavy metals can be incorporated into bacterial biomass which may then be removed during periodic sludge removal.

\section{Conclusion}

Industrial oily wastewater treatment was studied using an aerobic laboratory-scale submerged MBR with an ultrafiltration membrane module. The MBR system was run continuously for 50 days, and numerous water quality parameters were measured on a daily basis to evaluate the system performance and removal efficiency. Various analytical methods were developed and used to evaluate the 
performance of the MBR system. Solid-phase extraction was used to concentrate and transfer the target analytes from an aqueous to organic matrix, suitable for GC-MS analysis. Extraction recoveries were in the range 91-106 and $80-113 \%$ for PAHs and alkanes, respectively.

During the MBR treatment, TAH, TAH-LO and total PAHs were removed up to 96.0, 98.0 and $99.8 \%$, respectively, after the system reached an equilibrium steady state. The MBR effluent was visually clear, and its chemistry was stable even with varying influent COD from 860 to $1360 \mathrm{mg} / \mathrm{L}$. After reaching a treatment equilibrium state, the average COD was about $99 \mathrm{mg} / \mathrm{L}$. This represents an overall organic load removal rate of 88 to $93 \%$ over the course of the experiment. Furthermore, it was determined that degradation of aliphatic hydrocarbons and COD follow first-order kinetics. The half-lives for COD, TAH and TAH-LO were about 1,5 and 9 days, respectively. Biodegradation kinetics of PAHs could not be determined due to a rapid and high removal efficiency of the treatment process. Kinetic data are important in determining and predicting rates of degradation. This research was the first study on kinetics of treating hydrocarbons using MBR.

Based on the observed results, it was demonstrated that MBR treatment provides an efficient approach in treating petroleum hydrocarbons including both aliphatic and aromatic compounds. This method directly addresses issues of environmental concern on petroleum contamination, as wastewater discharge criteria become more stringent.

Acknowledgments The authors would like to acknowledge the financial support from Acadia University and the Natural Sciences and Engineering Research Council of Canada (NSERC, Engage Grant, EGP 419583-11). In addition, the authors would like to thank Avik Jim Ghoshdastidar, Dr. Yiming Zeng (Superstring MBR Technology, Corp.) and Garnet Loomer (Loomer's Pumping Service Limited) for their technical assistance and helpful discussion in this project.

\section{References}

Brown K, Ghoshdastidar AJ, Hanmore J, Frazee J, Tong AZ (2013) Membrane bioreactor technology: a novel approach to the treatment of compost leachate. Waste Manage 33:2188-2194

Canadian Council of Ministers of the Environment (2003) Canadian water quality guidelines for the protection of aquatic life

Clesceri LS, Greenberg AE, Trussell RR (1989) Standard methods for the examination of water and wastewater. American Public Health Association, Washington, DC

Dorival-García N, Zafra-Gómez A, Oliver-Rodríguez B, Navalón A, González-López J, Vílchez J (2014) Effect of the injection of pure oxygen into a membrane bioreactor on the elimination of bisphenol A. Int J Environ Sci Technol 11:9-20

Duan ZH, Pan LM, Wang H, Li NT (2013) Analysis of bacterial communities in $\mathrm{A} 2 \mathrm{O}$ membrane bioreactor treating oily wastewater. Adv Mater Res 641:87-91
Fakhru'l-Razi A, Pendashteh A, Abidin ZZ, Abdullah LC, Biak DRA, Madaeni SS (2010) Application of membrane-coupled sequencing batch reactor for oilfield produced water recycle and beneficial re-use. Bioresour Technol 101:6942-6949

Federal-Provincial-Territorial Committee on Drinking Water (2014) Guidelines for Canadian drinking water quality summary table. Health Canada

Ghoshdastidar AJ, Tong AZ (2013) Treatment of 2, 4-D, mecoprop, and dicamba using membrane bioreactor technology. Environ Sci Pollut Res 20:5188-5197

Ghoshdastidar AJ, Saunders J, Brown K, Tong AZ (2012) Membrane bioreactor treatment of commonly used organophosphate pesticides. J Environ Sci Health, Part B 47:745-750

Khan Y, Yamsaengsung R, Chetpattananondh P, Khongnakorn W (2015) Treatment of wastewater from biodiesel plants using microbiological reactor technology. Int J Environ Sci Technol 12:297-306

Lin H, Peng W, Zhang M, Chen J, Hong H, Zhang Y (2013) A review on anaerobic membrane bioreactors: applications, membrane fouling and future perspectives. Desalination 314:169-188

Martín-Pascual J, Reboleiro-Rivas P, López-López C, GonzálezLópez J, Hontoria E, Poyatos J (2014) Influence of hydraulic retention time on heterotrophic biomass in a wastewater moving bed membrane bioreactor treatment plant. Int $\mathrm{J}$ Environ Sci Technol 11:1449-1458

Monette A (2014) Guide for reporting to the national pollutant release inventory, 2014 and 2015. Environment Canada

Ozgun H, Dereli RK, Ersahin ME, Kinaci C, Spanjers H, van Lier JB (2013) A review of anaerobic membrane bioreactors for municipal wastewater treatment: integration options, limitations and expectations. Sep Purif Technol 118:89-104

Pendashteh A, Fakhru'l-Razi A, Chuah T, Radiah AD, Madaeni S, Zurina Z (2010) Biological treatment of produced water in a sequencing batch reactor by a consortium of isolated halophilic microorganisms. Environ Technol 31:1229-1239

Pendashteh AR, Abdullah LC, Fakhru'l-Razi A, Madaeni SS, Abidin ZZ, Biak DRA (2012) Evaluation of membrane bioreactor for hypersaline oily wastewater treatment. Process Saf Environ Prot 90:45-55

Peters KE, Walters CC, Moldowan MJ (2005) The biomarker guide: volume 2, biomarkers and isotopes in petroleum systems and earth history. Cambridge University Press, New York

Reyes-Avila J, Roldán-Carrillo T, Castorena-Cortés G, ZapataPeñasco I, Olguín-Lora P (2013) Effect of sulphur species on the hydrocarbon biodegradation of oil sludge generated by a gas processing facility Int J. Environ Sci Technol 10:551-558

Sawyer CN, McCarty PL, Parkin GF (2002) Chemistry for environmental engineering and science. McGraw-Hill, New York

Sharghi EA, Bonakdarpour B (2013) The study of organic removal efficiency and halophilic bacterial mixed liquor characteristics in a membrane bioreactor treating hypersaline produced water at varying organic loading rates. Bioresour Technol 149:486-495

Sharghi EA, Bonakdarpour B, Roustazade P, Amoozegar MA, Rabbani AR (2013) The biological treatment of high salinity synthetic oilfield produced water in a submerged membrane bioreactor using a halophilic bacterial consortium. J Chem Technol Biotechnol 88:2016-2026

Sharghi EA, Bonakdarpour B, Pakzadeh M (2014) Treatment of hypersaline produced water employing a moderately halophilic bacterial consortium in a membrane bioreactor: effect of salt concentration on organic removal performance, mixed liquor characteristics and membrane fouling. Bioresour Technol 164:203-213

Shariati SRP, Bonakdarpour B, Zare N, Ashtiani FZ (2011) The effect of hydraulic retention time on the performance and fouling 
characteristics of membrane sequencing batch reactors used for the treatment of synthetic petroleum refinery wastewater. Bioresour Technol 102:7692-7699

Wiszniowski J, Ziembinska A, Ciesielski S (2011) Removal of petroleum pollutants and monitoring of bacterial community structure in a membrane bioreactor. Chemosphere 83:49-56
Xu C, Guangxi M, Jiawei P, Zhe L, Jie L, Haixiao W (2014) Optimization of flocculation condition and Chlorella biomass harvesting research by pulse bubble dissolved air flotation. Renew Energ Resour 10:019 